\section{Social determinants of nonadherence to tuberculosis treatment in Buenos Aires, Argentina}

\author{
Determinantes sociales de la no adherencia al \\ tratamiento de la tuberculosis en Buenos Aires, \\ Argentina
}

\author{
Determinantes sociais da não-adesão ao \\ tratamento de tuberculose em Buenos Aires, \\ Argentina
}

\author{
Maria Belen Herrero 1,2 \\ Silvina Arrossi 1 \\ Silvina Ramos 1,3 \\ Jose Ueleres Braga ${ }^{4}$
}

\footnotetext{
${ }^{1}$ Centro de Estudios de Estado y Sociedad, Buenos Aires, Argentina.

2 Área de Relaciones

Internacionales, Facultad

Latinoamericana de Ciencias Sociales, Buenos Aires,

Argentina.

3 Consejo Nacional de Investigaciones Científicas

y Técnicas, Buenos Aires,

Argentina.

4 Instituto de Medicina Social, Universidade do Estado do

Rio de Janeiro, Rio de Janeiro, Brasil.

Correspondence

M. B. Herrero

Centro de Estudios de Estado y Sociedad.

Sanchez de Bustamante 27 Buenos Aires 1173, Argentina mbelen.herrero@gmail.com
}

\begin{abstract}
This study aimed to identify the individual and environmental determinants of nonadherence to tuberculosis (TB) treatment in selected districts in the Buenos Aires Metropolitan Area, in Argentina. We conducted a cross-sectional study using a hierarchical model. Using primary and secondary data, logistic regression was performed to analyze two types of determinants. The likelihood of nonadherence to treatment was greatest among male patients. The following factors led to a greater likelihood of nonadherence to treatment: patients living in a home without running water; head of household with out medical insurance; need to use more than one means of transport to reach the health center; place of residence in an area with a high proportion of households connected to the natural gas network; place of residence in an area where a large proportion of families fall below the minimum threshold of subsistence capacity; place of residence in an area where a high proportion of households do not have flushing toilets and basic sanitation. Our results show that social and economic factors - related to both individual and environmental characteristics - influence adherence to TB treatment.
\end{abstract}

Tuberculosis; Medication Adherence;

Epidemiologic Factors; Cross-sectional Studies

\section{Resumen}

El objetivo fue identificar los determinantes individuales y de área de la no adherencia al tratamiento de la tuberculosis (TB) en municipios de Buenos Aires, Argentina. Se realizó un estudio transversal con un modelo jerarquizado. El análisis se llevó a cabo mediante regresión logística múltiple en dos niveles, en base a datos primarios y secundarios. Los varones tuvieron mayor riesgo de no adherencia al tratamiento. La falta de provisión de agua en el hogar aumentó el riesgo de no adherencia. En aquellos hogares cuyo jefe de familia no tenía cobertura de salud también el riesgo de no adherencia fue mayor, al igual que en los pacientes que utilizaron más de un medio de transporte para llegar al centro de salud. En las áreas con mayor proporción de hogares con red de gas natural, mayor proporción de hogares con necesidades básicas instisfechas por la capacidad de subsistencia y mayor proporción de hogares que no tenían inodoros fue mayor el riesgo de no adherencia. Se concluye que los factores sociales y económicos tienen influencia sobre la adherencia al tratamiento, tanto a nivel individual, como de área.

Tuberculosis; Cumplimiento de la Medicación; Factores Epidemiológicos; Estudios Transversales 


\section{Introduction}

Although tuberculosis (TB) is a preventable and curable disease, it remains a significant public health problem in Argentina, where over 9,500 new cases are diagnosed and almost 800 people die from the disease every year 1 .

Although TB treatment in Argentina is free of charge, one of the main barriers to disease control is patient nonadherence to treatment and its consequences, i.e., disease progression and death, contagion, and the development of resistant strains 2 .

Treatment dropout rates in Argentina have risen over the last decade 3 . A cohort study of patients with smear-positive pulmonary tuberculosis carried out in Argentina in 2010 showed a treatment dropout rate of $13.8 \%$ (compared to the international target of reducing rates to $5 \%$ ).

A study conducted between 2008 and 2010 that analyzed treatment strategies and sociodemographic factors associated with treatment adherence in districts in the Buenos Aires Metropolitan Area - that account for around 10\% of the region's total population - showed that higher poverty levels and being treated in hospitals (as opposed to primary healthcare centers) were the main explanatory factors for nonadherence. Several studies have been conducted worldwide to identify the personal, environmental and health care factors associated with adherence to treatment 4,5,6,7,8,9,10,11,12.

In recent decades, the field of social epidemiology has shown a growing interest in comprehensive studies addressing both personal factors and factors related to the place of residence of patients. It is acknowledged that a wide range of proximal and distal social determinants, related to both individual and environmental characteristics, affect the health of a population 13,14. TB is considered a disease of poverty, and its distribution has been traditionally associated with different types of factors, ranging from individual characteristics and living conditions, to the characteristics of the place of residence. In the same way, it is believed that different types of factors influence adherence to treatment 15,16,17,18.

For this reason, the identification of personal characteristics and environmental characteristics connected with the place of residence of patients can advance our understanding of the social determinants of nonadherence to TB treatment 17,18,19. To date, only one article, encompassing a narrow spectrum of risk factors for dropping out of treatment, has addressed this issue in Argentina ${ }^{5}$. By using hierarchical factor analysis to explore different types of factors among a sample from selected districts of the Buenos Ai- res Metropolitan Area, the present study aims to identify individual and environmental (place of residence) determinants of nonadherence to $\mathrm{TB}$ treatment and investigate the influence of these different types of factors on adherence.

Information on the specific risk factors for treatment dropout is important for ensuring well-targeted surveillance measures. This study therefore aims to create new knowledge to improve the tuberculosis control strategies of the National Tuberculosis Control Program. In accordance with the principles expressed by the World Health Organization's Commission on the Social Determinants of Health, this study is a commitment to the value of equity and an evidencebased approach to understanding and action 20 .

\section{Material and methods}

This study comprises a cross-sectional analysis of primary and secondary data using quantitative methods of data collection and analysis.

\section{Setting}

The study was conducted in selected referral hospitals that treat TB in the following districts from the Sixth Health Region (HRVI) located in the southern part of the Buenos Aires Metropolitan Area: Almirante Brown, Avellaneda, Berazategui, Esteban Echeverría, Ezeiza, Lomas de Zamora, and Quilmes. The HRVI is the most populous region in the Province of Buenos Aires and accounts for a significant proportion of annual TB cases $(13 \%$ and $30 \%$ of the total number of notified cases in Argentina and the Province of Buenos Aires, respectively). In these districts, nonadherence to treatment among patients with smear-positive pulmonary tuberculosis in 2009 was $21.95 \%$ (range $12.5 \%$ to $35.57 \%$ ).

\section{Study population}

The study sample comprised patients aged 18 years and over residing in the selected districts and diagnosed and treated at health facilities during 2007. Patients who were referred to a health center not included in the study sample were excluded, as were patients who had spent most of their treatment under circumstances amounting to a deprivation of liberty (i.e., imprisonment), and patients with any kind of intellectual, mental, or physical disability that may have hindered or prevented their participation in the survey.

According to World Health Organization (WHO) and National Tuberculosis Control Program definitions, all eligible patients that inter- 
rupted treatment for 60 consecutive days or more were classified as nonadherent patients 21,22 . Adherent patients were all eligible patients who completed the stipulated treatment 22 .

\section{Design}

The first level of analysis - personal characteristics - used primary data obtained from the abovementioned sample. The study protocol (including the questionnaire) was approved by the Ethics Committees of all participating hospitals. After signing an informed consent form, patients were interviewed using a structured questionnaire. At the end of the interview, advice was provided to nonadherent patients about the importance of completing treatment. The questionnaire was pilot-tested with 10 patients (not included in the study sample) from the study area.

The second level of analysis - sociodemographic and socioeconomic characteristics of the place of residence of patients - used secondary data from the 2001 National Population, Household and Housing Census (anonymous census data obtained by electronic means from the Instituto Nacional de Estadísticas y Censos. http:// www.indec.gov.ar/, accessed on 27/Sep/2015).

\section{$\underline{\text { Statistical analysis }}$}

In contrast to prediction, the choice of the variables to be included in a statistical model is not based on a purely statistical association. The factors chosen by this study were chosen based on a conceptual framework which analyzed the hierarchical relationships the factors that influence adherence. As Victora et al. 23 note, certain factors may have an indirect influence on adherence and are therefore called proximal or distal determinants: the individual and environmental (place of residence) determinants in the present study. Distal factors are more likely to act through a number of inter-related proximate determinants (the individual determinants in the present study).

We therefore subdivided the proximate and distal determinants into hierarchically interrelated or parallel groups. As Victora et al. 23 note, studies commonly fail to adequately adjust environmental (distal) factors related to place of residence to individual (proximal) factors, thus reducing or eliminating the effects of the former. Therefore, knowledge of the environmental (place of residence) and individual determinants of nonadherence is essential to build a conceptual framework. In this study, the first level of analysis (personal characteristics) included information on the sociodemographic characteristics of pa- tients and heads of households, housing, disease, treatment, and access to health services. The second level of analysis included information on sociodemographic and socioeconomic characteristics relating to the place of residence of patients based on the census tracts of the 2001 National Population, Household and Housing Census. One of the indicators used was the unsatisfied basic needs (UBN), a proxy indicator of poverty based upon the threshold of subsistence capacity that considers the ratio between the number of employed family members and the total number of family members, and the level of education of the head of the household. The characteristics of the place of residence for each sample member were defined according to the census tract of the patient's place of residence and expressed as a percentage or divided into subsets (lower and upper), depending on the type of characteristic.

The data was analyzed using the Stata 10.0 (StataCorp., Colege Station, USA) software package. First, an exploratory bivariate analysis of both levels of characteristics was performed to assess sample distribution. Multiple regression analysis was then performed with variables that showed a significant level of correlation $(p<0.2)$ and those that were deemed essential for the explanatory model. Those variables that showed a statistically significant association $(p<0.05)$ were retained. Finally, a hierarchical analysis was performed for both levels and the variables associated with the outcome with a significance level of 0.05 were preserved. The dependent variable was "noncompliance".

\section{Results}

The final sample comprised 123 patients from an initial total of 193 eligible patients (64\%), of which 38 were nonadherent and 85 adherent. Forty (51\%) nonadherent patients and 30 (26\%) adherent patients were excluded because they could not be contacted either due to death, wrong address, or because the patient had moved to another district.

Tables 1 and 2 show the main sociodemographic and socioeconomic characteristics of the patients and their place of residence.

Table 3 shows the results of the bivariate and multivariate analyses for the first level of analysis (personal characteristics). The latter showed that male patients were three times more likely to not adhere to treatment $(\mathrm{OR}=2.91$; 95\%CI: 1.1-8.3). Patients without running water in their homes were five times more likely to interrupt treatment (OR $=4.74$; 95\%CI: 1.5-15.1), while those from households whose heads did not have health in- 
Table 1

Characteristics included in the first level of analysis (personal characteristics), adherent and nonadherent patients. Sixth Health Region (HRVI), Buenos Aires Metropolitan Area, Argentina.

\begin{tabular}{|c|c|c|c|c|c|c|}
\hline \multirow[t]{3}{*}{ Characteristics } & \multicolumn{6}{|c|}{ First level of analysis (personal characteristics) } \\
\hline & \multicolumn{2}{|c|}{ Adherent } & \multicolumn{2}{|c|}{ Nonadherent } & \multicolumn{2}{|c|}{ Total } \\
\hline & $\mathrm{n}$ & $\%$ & $\mathrm{n}$ & $\%$ & $\mathrm{n}$ & $\%$ \\
\hline \multicolumn{7}{|l|}{ Sex } \\
\hline Female & 43 & 50.6 & 12 & 31.6 & 55 & 44.7 \\
\hline Male & 42 & 49.4 & 26 & 68.4 & 68 & 55.3 \\
\hline Total & 85 & 100.0 & 38 & 100.0 & 123 & 100.0 \\
\hline \multicolumn{7}{|l|}{ Residence } \\
\hline Lives with somebody & 78 & 91.8 & 32 & 84.2 & 110 & 89.4 \\
\hline Lives alone & 7 & 8.2 & 6 & 15.8 & 13 & 10.6 \\
\hline Total & 85 & 100.0 & 38 & 100.0 & 123 & 100.0 \\
\hline \multicolumn{7}{|l|}{ Health insurance } \\
\hline Yes & 19 & 22.4 & 6 & 15.8 & 25 & 20.3 \\
\hline No & 66 & 77.7 & 32 & 84.2 & 98 & 79.7 \\
\hline Total & 85 & 100.0 & 38 & 100.0 & 123 & 100.0 \\
\hline \multicolumn{7}{|l|}{ Work situation } \\
\hline Working & 58 & 68.2 & 25 & 65.8 & 83 & 67.5 \\
\hline Not working & 27 & 31.8 & 13 & 34.2 & 40 & 32.5 \\
\hline Total & 85 & 100.0 & 38 & 100.0 & 123 & 100.0 \\
\hline \multicolumn{7}{|l|}{ Water supply } \\
\hline House connected & 68 & 81.0 & 22 & 57.9 & 90 & 73.8 \\
\hline Outside/On-plot & 16 & 19.1 & 16 & 42.1 & 32 & 26.2 \\
\hline Total & 84 & 100.0 & 38 & 100.0 & 122 * & 100.0 \\
\hline \multicolumn{7}{|l|}{ Sanitation services } \\
\hline Flushing toilet & 57 & 67.1 & 21 & 55.3 & 78 & 63.4 \\
\hline Nonflushing toilet & 26 & 30.6 & 14 & 36.8 & 40 & 32.5 \\
\hline Pit latrine & 2 & 2.4 & 3 & 7.9 & 5 & 4.1 \\
\hline Total & 85 & 100.0 & 38 & 100.0 & 123 & 100.0 \\
\hline \multicolumn{7}{|l|}{ Head of household health insurance } \\
\hline Yes & 28 & 32.9 & 6 & 15.8 & 34 & 27.6 \\
\hline No & 57 & 67.1 & 32 & 84.2 & 89 & 72.4 \\
\hline Total & 85 & 100.0 & 38 & 100.0 & 123 & 100.0 \\
\hline \multicolumn{7}{|l|}{ Work status of head of household } \\
\hline Employed & 72 & 85.7 & 30 & 79.0 & 102 & 83.6 \\
\hline Unemployed/Inactive & 12 & 14.3 & 8 & 21.1 & 20 & 16.4 \\
\hline Total & 84 & 100.0 & 38 & 100.0 & 122 * & 100.0 \\
\hline \multicolumn{7}{|l|}{ Household income level } \\
\hline Over US\$245 & 23 & 27.7 & 8 & 21.1 & 31 & 25.6 \\
\hline Between US\$124 and US\$245 & 44 & 53.0 & 13 & 34.2 & 57 & 47.1 \\
\hline Up to US\$123 & 16 & 19.3 & 17 & 44.7 & 33 & 27.3 \\
\hline Total & 83 & 100.0 & 38 & 100.0 & 121 ** & 100.0 \\
\hline \multicolumn{7}{|c|}{ Type of health facility where treatment was provided } \\
\hline Primary Health Centre & 33 & 38.8 & 7 & 18.4 & 40 & 32.5 \\
\hline Referral hospital & 52 & 61.2 & 31 & 81.6 & 83 & 67.5 \\
\hline Total & 85 & 100.0 & 38 & 100.0 & 123 & 100.0 \\
\hline \multicolumn{7}{|c|}{ Type health facility where control visits were carried out } \\
\hline Primary Health Centre/Other & 33 & 38.8 & 6 & 15.8 & 39 & 31.7 \\
\hline Referral hospital & 52 & 61.2 & 32 & 84.2 & 84 & 68.3 \\
\hline Total & 85 & 100.0 & 38 & 100.0 & 123 & 100.0 \\
\hline
\end{tabular}


Table 1 (continued)

\begin{tabular}{|c|c|c|c|c|c|c|}
\hline \multirow[t]{3}{*}{ Characteristics } & \multicolumn{6}{|c|}{ First level of analysis (personal characteristics) } \\
\hline & \multicolumn{2}{|c|}{ Adherent } & \multicolumn{2}{|c|}{ Nonadherent } & \multicolumn{2}{|c|}{ Total } \\
\hline & $\mathrm{n}$ & $\%$ & $\mathrm{n}$ & $\%$ & $\mathrm{n}$ & $\%$ \\
\hline \multicolumn{7}{|c|}{$\begin{array}{l}\text { Received sufficient information about the disease and the } \\
\text { treatment }\end{array}$} \\
\hline Yes & 83 & 97.7 & 33 & 86.8 & 116 & 94.3 \\
\hline No & 2 & 2.4 & 5 & 13.2 & 7 & 5.7 \\
\hline Total & 85 & 100.0 & 38 & 100.0 & 123 & 100.0 \\
\hline \multicolumn{7}{|c|}{$\begin{array}{l}\text { Was granted leaves of absence from work to visit the health } \\
\text { center }\end{array}$} \\
\hline Yes & 81 & 95.3 & 29 & 76.3 & 110 & 89.4 \\
\hline No & 4 & 4.7 & 9 & 23.7 & 13 & 10.6 \\
\hline Total & 85 & 100.0 & 38 & 100.0 & 123 & 100.0 \\
\hline \multicolumn{7}{|c|}{ Difficulties in cost of transportation } \\
\hline No & 46 & 55.4 & 12 & 32.4 & 58 & 48.3 \\
\hline Yes & 37 & 44.6 & 25 & 67.6 & 62 & 51.7 \\
\hline Total & 83 & 100.0 & 37 & 100.0 & 120 *** & 100.0 \\
\hline \multicolumn{7}{|c|}{ Difficulties with transportation time } \\
\hline No & 65 & 78.3 & 24 & 64.9 & 89 & 74.2 \\
\hline Yes & 18 & 21.7 & 13 & 35.1 & 31 & 25.8 \\
\hline Total & 83 & 100.0 & 37 & 100.0 & $120 * \star *$ & 100.0 \\
\hline \multicolumn{7}{|c|}{ Number of means of transport used to visit the health center } \\
\hline One & 64 & 84.2 & 24 & 70.6 & 88 & 80.0 \\
\hline More than one & 12 & 15.8 & 10 & 29.4 & 22 & 20.0 \\
\hline Total & 76 & 100.0 & 34 & 100.0 & $110 \#$ & 100.0 \\
\hline \multicolumn{7}{|l|}{ TB/HIV co-infection } \\
\hline No & 83 & 97.7 & 35 & 92.1 & 118 & 95.9 \\
\hline Yes & 2 & 2.35 & 3 & 7.9 & 5 & 4.1 \\
\hline Total & 85 & 100.0 & 38 & 100.0 & 123 & 100.0 \\
\hline \multicolumn{7}{|c|}{ Distance form health center } \\
\hline Less than $800 \mathrm{~m}$ & 2 & 2.4 & 2 & 5.3 & 4 & 3.3 \\
\hline Over $800 \mathrm{~m}$ & 83 & 97.7 & 36 & 94.7 & 119 & 96.8 \\
\hline Total & 85 & 100.0 & 38 & 100.0 & 123 & 100.0 \\
\hline \multicolumn{7}{|c|}{ Adequate knowledge of when treatment is to be concluded } \\
\hline Yes & 31 & 36.5 & 9 & 23.7 & 40 & 32.5 \\
\hline No & 54 & 63.5 & 29 & 76.3 & 83 & 67.5 \\
\hline Total & 85 & 100.0 & 38 & 100.0 & 123 & 100.0 \\
\hline
\end{tabular}

TB: tuberculosis.

* 1 missing;

** 2 missings;

*** 3 missings;

\# 13 non-apllicable.

surance were six times more likely to not adhere $(\mathrm{OR}=5.74$; 95\%CI: 1.5-21.9). Patients receiving treatment at referral hospitals were five times more likely than primary health care center patients to interrupt treatment $(\mathrm{OR}=4.54$; 95\%CI: 1.2-16.8). Patients who did not receive sufficient information were 10 times more likely to not adhere to treatment $(\mathrm{OR}=10.36$; 95\%CI: 1.6-68.3), and those who were not granted leave of absence to carry out checkups were almost eight times more likely to not adhere $(\mathrm{OR}=7.78$; 95\%CI: 1.2 51.9). Finally, patients who had to use more than one means of transport were almost five times more likely not to adhere to treatment than those using only one means (OR = 4.7; 95\%CI: 1.3-16.3). 
Characteristics included in the second level of analysis (environmental characteristics related to place of residence), adherent and nonadherent patients. Sixth Health Region (HRVI), Buenos Aires Metropolitan Area, Argentina.

\begin{tabular}{|c|c|c|c|c|c|c|}
\hline \multirow[t]{3}{*}{ Characteristics } & \multicolumn{6}{|c|}{ Second level of analysis (environmental characteristics related to place of residence) } \\
\hline & \multicolumn{2}{|c|}{ Adherent } & \multicolumn{2}{|c|}{ Nonadherent } & \multicolumn{2}{|c|}{ Total } \\
\hline & $\mathbf{n}$ & $\%$ & n & $\%$ & $\mathbf{n}$ & $\%$ \\
\hline \multicolumn{7}{|c|}{ Condition of street lighting } \\
\hline Good & 59 & 69.4 & 20 & 47.4 & 79 & 65.2 \\
\hline Bad & 26 & 30.6 & 18 & 52.6 & 44 & 35.8 \\
\hline Total & 85 & 100.0 & 38 & 100.0 & 123 & 100.0 \\
\hline \multicolumn{7}{|l|}{ Natural gas network } \\
\hline In good condition & 50 & 58.8 & 28 & 73.7 & 78 & 63.4 \\
\hline In bad condition & 35 & 41.2 & 10 & 26.3 & 45 & 36.6 \\
\hline Total & 85 & 100.0 & 38 & 100.0 & 123 & 100.0 \\
\hline \multicolumn{7}{|l|}{ Subsistence capacity } \\
\hline Below threshold & 54 & 63.5 & 16 & 42.1 & 70 & 56.9 \\
\hline Above threshold & 31 & 36.5 & 22 & 57.9 & 53 & 43.1 \\
\hline Total & 85 & 100.0 & 38 & 100.0 & 123 & 100.0 \\
\hline \multicolumn{7}{|l|}{ Inactive population } \\
\hline Lower subset & 39 & 45.9 & 23 & 60.5 & 62 & 50.4 \\
\hline Upper subset & 46 & 54.1 & 15 & 39.5 & 61 & 49.6 \\
\hline Total & 85 & 100.0 & 38 & 100.0 & 123 & 100.0 \\
\hline \multicolumn{7}{|c|}{ Flushing toilet and basic sanitation } \\
\hline Upper subset & 37 & 43.5 & 11 & 29.0 & 48 & 39.0 \\
\hline Lower subset & 48 & 56.5 & 27 & 71.1 & 75 & 61.0 \\
\hline Total & 85 & 100.0 & 38 & 100.0 & 123 & 100.0 \\
\hline \multicolumn{7}{|l|}{ Self-employed workers } \\
\hline Lower subset & 48 & 56.5 & 16 & 42.1 & 64 & 52.0 \\
\hline Upper subset & 37 & 43.5 & 22 & 57.9 & 59 & 48.0 \\
\hline Total & 85 & 100.0 & 38 & 100.0 & 123 & 100.0 \\
\hline \multicolumn{7}{|c|}{ Completed primary education } \\
\hline Upper subset & 44 & 51.8 & 27 & 71.1 & 71 & 57.7 \\
\hline Lower subset & 41 & 48.2 & 11 & 29.0 & 52 & 42.3 \\
\hline Total & 85 & 100.0 & 38 & 100.0 & 123 & 100.0 \\
\hline
\end{tabular}

Table 4 shows the results of the bivariate and multivariate analyses for the second level of analysis (place of residence). The latter showed that nonadherence was more likely in areas where a large proportion of households were connected to the natural gas network $(\mathrm{OR}=0.25 ; 95 \% \mathrm{CI}$ : $0.1-0.7)$. Also, patients living in areas with a large proportion of households under the subsistence capacity threshold were three times more likely to not adhere to treatment $(\mathrm{OR}=3.4$; 95\%CI: 1.4-8.5). The lack of a flushing toilet and basic sanitation led to a three-fold increase in the likelihood of nonadherence (OR = 3.39; 95\%CI: 1.2 9.4). On the other hand, likelihood was lower in areas where a large proportion of the population was inactive $(\mathrm{OR}=0.3$; 95\%CI: 0.1-0,8). Finally, the likelihood of nonadherence was also higher in areas with a high proportion of self-employed workers (OR $=2.84$; 95\%CI: 1.1-7.7).

The results of the hierarchical analysis (Table 5) show that male patients are three times more likely to not adhere to treatment (OR = 3.53; 95\%CI: 1.23-10.11). Moreover, nonadherence was four times more likely in households without running water than in households with this service (OR $=4.18$; 95\%CI: 1.29-13. 47). The likelihood of nonadherence was six times greater in households whose head did not have health insurance $(\mathrm{OR}=5.47$; 95\%CI: 1.36-21.93). Additionally, patients who had to use more than one means of transport were almost seven times more likely to not adhere to treatment 
Table 3

Bivariate and multivariate analysis of factors associated with nonadherence to tuberculosis (TB) treatment at the first level of analysis (personal characteristics), adherent and nonadherent patients. Sixth Health Region (HRVI), Buenos Aires Metropolitan Area, Argentina.

\begin{tabular}{|c|c|c|c|c|c|c|c|}
\hline \multirow[t]{2}{*}{ Characteristics } & \multirow[t]{2}{*}{$\%$} & \multicolumn{3}{|c|}{ Bivariate analysis } & \multicolumn{3}{|c|}{ Multivariate analysis } \\
\hline & & OR crude & $95 \% \mathrm{Cl}$ & p-value & OR adjusted & $95 \% \mathrm{Cl}$ & $\mathrm{p}$-value \\
\hline \multicolumn{8}{|l|}{ Sex } \\
\hline Female & 31.6 & 1.00 & & & 1.00 & & \\
\hline Male & 68.4 & 2.20 & $1.0-5.0$ & 0.053 & 2.91 & $1.1-8.3$ & 0.047 \\
\hline \multicolumn{8}{|l|}{ Water supply } \\
\hline House connected & 57.9 & 1.00 & & & 1.00 & & \\
\hline Outside/on-plot & 42.1 & 3.10 & $1.3-7.2$ & 0.009 & 4.74 & $1.5-15.1$ & 0.009 \\
\hline \multicolumn{8}{|l|}{ Sanitation services } \\
\hline Flushing toilet & 55.3 & & & & & & \\
\hline Nonflushing toilet & 36.8 & & & & & & \\
\hline Pit latrine & 7.9 & 1.70 & $0.9-3.2$ & 0.122 & & & \\
\hline \multicolumn{8}{|c|}{ Head of household health insurance } \\
\hline Yes & 15.8 & 1.00 & & 1.0 & 1.00 & & \\
\hline No & 84.2 & 2.60 & $0.9-6.9$ & 0.055 & 5.74 & $1.5-21.9$ & 0.011 \\
\hline \multicolumn{8}{|l|}{ Household income level } \\
\hline Over US\$245 & 21.1 & 1.00 & & & & & \\
\hline Between US\$124 and U\$245 & 34.2 & & & & & & \\
\hline Up to US\$123 & 44.7 & 1.90 & $1.1-3.3$ & 0.027 & & & \\
\hline \multicolumn{8}{|c|}{ Type of health facility where treatment was provided } \\
\hline Primary Health Centre & 18.4 & 1.00 & & & & & \\
\hline Referral hospital & 81.6 & 2.80 & 1.1-7.1 & 0.029 & & & \\
\hline \multicolumn{8}{|c|}{ Type of health facility where control visits were carried out } \\
\hline Primary Health Centre/Other & 15.8 & 1.00 & & & 1.00 & & \\
\hline Referral hospital & 84.2 & 3.40 & 1.3-9.0 & 0.014 & 4.54 & $1.2-16.8$ & 0.023 \\
\hline \multicolumn{8}{|c|}{ Received sufficient information about the disease and treatment } \\
\hline Yes & 86.8 & 1.00 & & & 1.00 & & \\
\hline No & 13.2 & 6.30 & $1.2-3.4$ & 0.033 & 10.36 & $1.6-68.3$ & 0.015 \\
\hline \multicolumn{8}{|c|}{ Was granted leave of absence from work to visit the health center } \\
\hline Yes & 76.3 & 1.00 & & & 1.00 & & \\
\hline No & 23.7 & 6.30 & $1.8-2.2$ & 0.004 & 7.78 & $1.2-51.9$ & 0.034 \\
\hline \multicolumn{8}{|l|}{ Difficulties transport costs } \\
\hline No & 32.4 & 1.00 & & & & & \\
\hline Yes & 67.6 & 2.60 & $1.2-5.9$ & 0.022 & & & \\
\hline \multicolumn{8}{|l|}{ Difficulties transport time } \\
\hline No & 64.9 & 1.00 & & & & & \\
\hline Yes & 35.1 & 1.96 & $0.8-4.6$ & 0.123 & & & \\
\hline \multicolumn{8}{|c|}{ Number of means of transport used to visit the health center } \\
\hline One & 70.6 & 1.00 & & & 1.00 & & \\
\hline More than one & 29.4 & 2.22 & $0.9-5.8$ & 0.104 & 4.70 & $1.3-16.3$ & 0.017 \\
\hline \multicolumn{8}{|l|}{ TB/HIV co-infection } \\
\hline No & 92.1 & 1.00 & & & & & \\
\hline Yes & 7.9 & 3.60 & $0.6-2.2$ & 0.175 & & & \\
\hline \multicolumn{8}{|c|}{ Adequate knowledge of completion of treatment } \\
\hline Yes & 23.7 & 1.00 & & & & & \\
\hline No & 76.3 & 1.85 & $0.8-4.4$ & 0.165 & & & \\
\hline
\end{tabular}

95\% Cl: 95\% confidence interval. 
Bivariate and multivariate analysis of factors associated with nonadherence to tuberculosis (TB) treatment at the second level of analysis (environmental characteristics related to place of residence), adherent and nonadherent patients. Sixth Health Region (HRVI), Buenos Aires Metropolitan Area, Argentina.

\begin{tabular}{|c|c|c|c|c|c|c|c|}
\hline \multirow[t]{2}{*}{ Characteristics } & \multirow[t]{2}{*}{$\%$} & \multicolumn{3}{|c|}{ Bivariate analysis } & \multicolumn{3}{|c|}{ Multivariate analysis } \\
\hline & & OR crude & $95 \% \mathrm{Cl}$ & $\mathrm{p}$-value & OR adjusted & $95 \% \mathrm{Cl}$ & $p$-value \\
\hline \multicolumn{8}{|c|}{ Condition of street lighting } \\
\hline Good & 47.4 & 1.00 & & & & & \\
\hline Bad & 52.6 & 2.04 & $0.9-4.5$ & 0.075 & & & \\
\hline \multicolumn{8}{|l|}{ Natural gas network } \\
\hline In good condition & 73.7 & 1.00 & & & 1.00 & & \\
\hline In bad condition & 26.3 & 0.51 & $0.2-1.1$ & 0.117 & 0.25 & $0.1-0.7$ & 0.012 \\
\hline \multicolumn{8}{|l|}{ Subsistence capacity } \\
\hline Below threshold & 42.1 & 1.00 & & & 1.00 & & \\
\hline Above threshold & 57.9 & 2.39 & $1.1-5.2$ & 0.028 & 3.40 & $1.4-8.5$ & 0.007 \\
\hline \multicolumn{8}{|l|}{ Inactive population } \\
\hline Lower subset & 60.5 & 1.00 & & & 1.00 & & \\
\hline Upper subset & 39.5 & 0.55 & $0.3-1.2$ & 0.135 & 0.31 & $0.1-0.8$ & 0.022 \\
\hline \multicolumn{8}{|l|}{ Self-employed workers } \\
\hline Lower subset & 42.1 & 1.00 & & & 1.00 & & \\
\hline Upper subset & 57.9 & 1.78 & $0.8-3.9$ & 0.143 & 2.84 & $1.1-7.7$ & 0.04 \\
\hline \multicolumn{8}{|c|}{ Flushing toilet and basic sanitation } \\
\hline Upper subset & 29.0 & 1.00 & & & 1.00 & & \\
\hline Lower subset & 71.1 & 1.89 & $0.8-4.3$ & 0.128 & 3.39 & $1.2-9.4$ & 0.018 \\
\hline \multicolumn{8}{|c|}{ Completed primary education } \\
\hline Upper subset & 71.1 & 1.00 & & & & & \\
\hline Lower subset & 29.0 & 0.44 & $0.2-1.0$ & 0.048 & & & \\
\hline
\end{tabular}

95\% $\mathrm{Cl}$ : 95\% confidence interval.

Source: 2001 National Population, Household and Housing Census (Instituto Nacional de Estadísticas y Censos. http://www.indec.gov.ar/, accessed on 27/Sep/2015).

than those using only one means $(\mathrm{OR}=6.47$; 95\%CI: 1.7-24.6). The analysis also showed that patients living in areas with a large proportion of households under the subsistence capacity threshold were three times more likely to not adhere to treatment $(\mathrm{OR}=3,04$; 95\%CI: 1.07-8.82). Nonadherence was more likely in areas where a large proportion of households were connected to the natural gas network $(\mathrm{OR}=0.18 ; 95 \% \mathrm{CI}$ : 0.05-0.59). Finally, the likelihood of nonadherence was five times greater in areas where a large proportion of households lacked a flushing toilet and basic sanitation than in areas that had these services $(\mathrm{OR}=5.08$; 95\%CI: 1.51-17.1).

\section{Discussion}

To our knowledge, this is the first attempt to analyze the social determinants of nonadherence to TB treatment in Argentina considering the effects of both personal characteristics and the characteristics of the place of residence of the patients. Our findings show that several individual and environmental factors affect adherence to TB treatment.

The results show that men are more likely to not adhere to treatment than women. Several studies addressing the relationship between gender and nonadherence ascribe this association to the fact that the heads of household are generally men and working men therefore have greater difficulty visiting a health center 24 . The majority of the heads of households interviewed by this study were men (72\%), corroborating these findings. However, other studies have identified other factors which explain the higher likelihood 
Results of the final hierarchical model showing factors influencing nonadherence to tuberculosis (TB) treatment. Sixth Health Region (HRVI), Buenos Aires Metropolitan Area, Argentina.

\begin{tabular}{|c|c|c|c|c|}
\hline \multirow[t]{2}{*}{ Characteristics } & \multicolumn{4}{|c|}{ Hierarchical model } \\
\hline & $\%$ & OR adjusted & $95 \% \mathrm{Cl}$ & p-value \\
\hline \multicolumn{5}{|l|}{ Sex } \\
\hline Female & 31.6 & 1.00 & & \\
\hline Male & 68.4 & 3.53 & $1.2-10.1$ & 0.018 \\
\hline \multicolumn{5}{|l|}{ Water supply } \\
\hline House connected & 57.9 & 1.00 & & \\
\hline Outside/on-plot & 42.1 & 4.18 & $1.3-13.5$ & 0.016 \\
\hline \multicolumn{5}{|c|}{ Head of household health insurance } \\
\hline Yes & 15.8 & 1.00 & & \\
\hline No & 84.2 & 5.47 & $1.4-21.9$ & 0.016 \\
\hline \multicolumn{5}{|c|}{ Number of means of transport } \\
\hline One & 70.6 & 1.00 & & \\
\hline More than one & 29.4 & 6.47 & $1.7-24.6$ & 0.006 \\
\hline \multicolumn{5}{|l|}{ Natural gas network } \\
\hline In good condition & 73.7 & 1.00 & & \\
\hline In bad condition & 26.3 & 0.18 & $0.1-0.6$ & 0.005 \\
\hline \multicolumn{5}{|l|}{ Subsistence capacity } \\
\hline Below threshold & 42.1 & 1.00 & & \\
\hline Above threshold & 57.9 & 3.04 & $1.1-8.6$ & 0.035 \\
\hline \multicolumn{5}{|c|}{ Flushing toilet and basic sanitation } \\
\hline Upper subset & 29.0 & 1.00 & & \\
\hline Lower subset & 71.1 & 5.08 & $1.5-17.1$ & 0.009 \\
\hline
\end{tabular}

95\% $\mathrm{Cl}: 95 \%$ confidence interval.

of treatment interruption among males 7,25, such as alcohol and drug abuse, and smoking.

Our results show that the likelihood of nonadherence is greater among patients living in households whose heads did not have medical insurance. This concurs with findings of other studies that showed an increased likelihood of nonadherence among patients without health insurance, even when treatment was free of charge 24,26 . These studies suggest that the loss of income due to health problems is a significant factor affecting treatment adherence, particularly in the case of workers with no health insurance or social protection who therefore have no income when they stop working (in contrast to salaried workers) 24,26 .

Another factor associated with nonadherence to treatment is the lack of running water in the home, which is an indicator of structural poverty in Argentina (Instituto Nacional de Estadísticas y Censos. http://www.indec.gov.ar/, accessed on $27 /$ Sep/2015). Various studies worldwide have highlighted the association between nonadherence to TB treatment and poverty, despite the fact that treatment is free of charge $6,7,8,9,10,27,28$. These studies show that low socioeconomic status negatively influences adherence due to the direct and indirect costs of treatment, such as transport, additional medication, and even the time spent on treatment (i.e., time spent away from work) $6,7,28$. Our study suggests that other factors also affect adherence among patients with low socioeconomic status. Patients who have to use more than one means of transport to visit the health center were five times more likely to not adhere than patients who only use one means. Several studies show that high transport costs reduce the patient's capacity to continue treatment, particularly those with a low socioeconomic status 6,7,11. In our study, household income was lower among nonadherent patients than in adherent patients. However, this variable was excluded from the final model due to the small sample size. Further research is needed to analyze the influence of indirect costs on patients' capacity to adhere to treatment, particularly in high poverty contexts. 
The majority of nonadherent patients in our sample are from families with low socioeconomic status. Our results suggest that the likelihood of nonadherence is greater among patients living in areas where a high proportion of households do not have a flushing toilet or basic sanitation. This is one of the indicators of structural poverty in Argentina, and one of the components of the $U B N$ Index. Our results corroborate the findings of other studies that show that health is affected by living conditions, particularly in areas with high levels of high poverty and social inequality 29. Moreover, the risk of treatment dropout was higher in areas where a large proportion of families fall below the minimum threshold of subsistence capacity. This is a proxy indicator of household income based on the ratio between the number of employed family members and total number of family members, and the level of education of the head of the household 30,31. Studies that included level of education as a variable show that illiterate patients (or patients who have a low level of education) are generally 1.3 to 1.7 times more likely to dropout of treatment than patients with a higher level of education 27,32,33. A study conducted in Southern India shows that level of education influences patient health behavior due to its association with low income and work status, and low levels of knowledge regarding treatment 34 .

Our study has certain limitations. First, the smallest spatial units of collection were the census tracts determined by the provincial government based on convenience, rather than on social criteria 35 . Thus, the heterogeneity of the shape, area and population size of these tracts (for example, the population of certain census tracts was over 1,500), together with the possibility of income variation within each census unit, is a limiting factor and may lead to a underestimation of the relationship between the environmental characteristics (place of residence) and nonadherence. Second, the small sample size may affect analysis and the generalization of results to a larger universe of patients with $\mathrm{TB}$, particularly with respect to environmental characteristics. We believe that further research is needed to assess aspect.

However, this study has a number of strengths. First, despite losing significance in the final model, the bivariate analysis showed a significant association between nonadherence to treatment and a number of individual and environmental characteristics. This fact shows that nonadherence is socially determined and that, at least among this sample, there is a connection between nonadherence and poor living conditions and poverty in the place of residence. Further research is required, not only to gain greater insight into the connection between individual and environmental characteristics and nonadherence to treatment, but also to assess the relative contribution of each factor and determine which factor has the greatest influence: being poor or living in a poor area.

\section{Conclusion}

Our findings show that social and economic factors - related to both individual and environmental (place of residence) characteristics - influence adherence to TB treatment. Strategies to reduce treatment dropout should address the multiplicity of factors that influence adherence and prioritize social protection interventions for the most socially and economically vulnerable patients, including the provision of individual and family support. We also believe that further research into the social determinants of nonadherence to treatment is essential for tackling the individual and environmental factors that lead to nonadherence. 


\section{Resumo}

O objetivo deste trabalho foi identificar os determinantes individuais e de área da não-adesão ao tratamento da tuberculose (TB) em municípios de Buenos Aires, Argentina. Foi realizado um estudo transversal com um modelo hierarquizado. A análise dos determinantes foi realizada em dois níveis por meio de análise de regressão logística em dois niveis, com base em dados primários e secundários. Além disso, a falta de abastecimento de água em casa aumentou o risco de não-adesão. Nesses domicílios, cujo chefe de família não tinha a cobertura de saúde, também o risco de não-adesão foi maior, como em pacientes que usaram mais de um meio de transporte para chegar ao centro de saúde. Em áreas com uma maior proporção de domicílios com uma rede de gás natural e com necessidades básicas insatisfeitas para os meios de vida e uma maior proporção de domicílios sem sanitários foi maior o risco de não-adesão. Conclui-se que os fatores sociais e econômicos influenciam a adesão ao tratamento da TB, tanto individualmente como em termos de área.

Tuberculose; Adesão à Medicação; Fatores Epidemiológicos; Estudos Transversais

\section{Contributors}

M. B. Herrero participated in protocol design and data analysis, and was responsible in large part for preparing this manuscript. S. Arrossi was responsible for protocol design, participated in data analysis, and in the writing of this manuscript. S. Ramos participated in protocol design, data analysis, and in the writing of this manuscript. J. U. Braga participated in data analysis and in the writing of this manuscript, and was responsible in large part for the final review of this manuscript.

\section{Acknowledgments}

The authors gratefully acknowledge: the support and resources provided by the Comisión Nacional Salud Investiga of the Ministry of Health of Argentina; the support of the Regional Director of the Tuberculosis Control Program in the Sixth Health Region; and all the patients who kindly participated in this study and shared their stories and made this study possible.

\section{References}

1. Instituto Nacional de Enfermedades Respiratorias. Notificación de casos de tuberculosis en la República Argentina. Período 1980-2011. Santa Fe: Instituto Nacional de Enfermedades Respiratorias Dr. Emilio Coni; 2012.

2. Centers for Disease Control and Prevention. Core curriculum on tuberculosis: what the clinician should know. 4th Ed. Atlanta: Centers for Disease Control and Prevention; 2000.

3. Instituto Nacional de Enfermedades Respiratorias. Resultado del tratamiento de la tuberculosis pulmonar $\mathrm{ED}(+)$ en la República Argentina: período 1980-2010. Santa Fe: Instituto Nacional de Enfermedades Respiratorias Dr. Emilio Coni; 2012.
4. Arrossi S, Herrero MB, Greco A, Ramos S. Factores predictivos de la no adherencia al tratamiento de la tuberculosis en municipios del Área Metropolitana de Buenos Aires, Argentina. Salud Colect 2012; 8 Suppl 1:S65-76.

5. Brasil PE, Braga JU. Meta-analysis of factors related to health services that predict treatment default by tuberculosis patients. Cad Saúde Pública 2008; 24 Suppl 4:485-502.

6. Mishra P, Hansen E, Sabroe S, Kafle K. Socio-economic status and adherence to tuberculosis treatment: a case-control study in a district of Nepal. Int J Tuberc Lung Dis 2005; 9:1134-9. 
7. Sosa Pineda N, Pereira S, Barreto M. Abandono del tratamiento de la tuberculosis en Nicaragua: resultados de un estudio comparativo. Rev Panam Salud Pública 2005; 17:271-8.

8. Herrero MB, Greco A, Ramos S, Arrossi S. Del riesgo individual a la vulnerabilidad social: factores asociados a la no adherencia al tratamiento de la tuberculosis. Rev Argent Salud Pública 2011; 2:36-42.

9. Sumartojo E. When tuberculosis treatment fails: a social behavioral account of patient adherence. Am Rev Respir Dis 2003; 147:1311-20.

10. Farmer P. Social scientists and the new tuberculosis. Soc Sci Med 1997; 44:347-58.

11. O’Boyle S, Power J, Ibrahim M, Watson J. Factors affecting patient compliance with anti-tuberculosis chemotherapy using the directly observed treatment short-course strategy (DOTS). Int J Tuberc Lung Dis 2002; 6:307-12.

12. Braga JU, Pinheiro JS, Matsuda JS, Barreto JAP, Feijão AMM. Fatores associados ao abandono do tratamento da tuberculose nos serviços de atenção básica em dois municípios brasileiros, Manaus e Fortaleza, 2006 a 2008. Cad Saúde Colet (Rio J.) 2012; 20:225-33.

13. Berkman LF, Kawachi I. A historical framework for social epidemiology. In: Berkman LF, Kawachi I, editors. Social epidemiology. New York: Oxford University Press; 2000. p. 3-12.

14. Diez Roux AV. A glossary for multilevel analysis. J Epidemiol Community Health 2002; 56:588-94.

15. Braga JU, Herrero MB, Cuellar CM. Transmissão da tuberculose na tríplice fronteira entre Brasil, Paraguai e Argentina. Cad Saúde Pública 2011; 27:1271-80.

16. Ximenes RA, Albuquerque MFPM, Souza WV, Montarroyos UR, Diniz GT, Luna CF, et al. Is it better to be rich in a poor area or poor in a rich area? A multilevel analysis of a case-control study of social determinants of tuberculosis. Int J Epidemiol 2009; 38:1285-96.

17. Gonçalves MJ, Leon AC, Penna ML. A multilevel analysis of tuberculosis associated factors. Rev Salud Pública 2009; 11:918-30.

18. Harling G, Ehrlich R, Myer L. The social epidemiology of tuberculosis in South Africa: a multilevel analysis. Soc Sci Med 2008; 66:492-505.

19. Sabaté E. Adherencia a los tratamientos a largo plazo: pruebas para la acción. Geneva: World Health Organization; 2004

20. Universidad del Desarrollo; National Institute for Health and Clinical Excellence.The social determinants of health: developing an evidence base for political action. Final report to World Health Organization Commission on the Social Determinants of Health. Santiago de Chile: Universidad del Desarrollo/London: National Institute for Health and Clinical Excellence; 2007.

21. World Health Organization. Treatment of tuberculosis: guidelines for national programmes. $3 \mathrm{rd} \mathrm{Ed}$. Geneva: World Health Organization; 2003.

22. Programa Nacional de Control de la Tuberculosis. Normas técnicas 2008. Santa Fe: Instituto Nacional de Enfermedades Respiratorias Dr. Emilio Coni; 2008.
23. Victora CG, Huttly SR, Fuchs SC, Olinto MT. The role of conceptual frameworks in epidemiological analysis: a hierarchical approach. Int J Epidemiol 1997; 26:224-7.

24. Balasubramanian VN, Oommen K, Samuel R. DOT or not? Direct observation of anti-tuberculosis treatment and patient outcomes, Kerala State, India. Int J Tuberc Lung Dis 2000; 4:409-13.

25. Vijay S, Balasangameswara VH, Jagannatha PS, Saroja VN, Shivashankar B, Jagota P. Re-treatment outcome of smear positive tuberculosis cases under DOTS in Bangalore city. Indian J Tuberc 2002; 49:195-204.

26. Nene B, Jayant K, Arrossi S, Shastri S, Budukh A, Hingmire S, et al. Determinants of women's participation in cervical cancer screening trial, Maharashtra, India. Bull World Health Organ 2007; 85:264-72.

27. Galiano M, Montesinos N. Modelo predictivo de abandono del tratamiento antituberculoso para la región Metropolitana de Chile. Enferm Clín 2005; 15:192-8.

28. Galdós-Tangüis H, Caylá JA, García de Olalla P, Jansá JM, Brugal MT. Factors predicting non-completion of tuberculosis treatment among HIV-infected patients in Barcelona (1987-1996). Int J Tuberc Lung Dis 2000; 4:55-60.

29. Kawachi I, Berkman LF. Social cohesion, social capital, and health. In: Berkman LF, Kawachi I, editors. Social epidemiology. New York: Oxford University Press; 2000. p. 174-90.

30. Feres JC, Mancero X. Enfoques para la medición de la pobreza: breve revisión de la literatura. Santiago de Chile: División de Estadística y Proyecciones Económicas, Comisión EConómica para América Latina y el Caribe; 2001. (CEPAL - Serie Estudios Estadísticos y Prospectivos).

31. Beccaria L, Carpio J, Orsatti A. Argentina: informalidad laboral en el nuevo modelo económico. In: Carpio J, Klein E y Novacovsky I, editors. Informalidad y exclusión social. Buenos Aires: Fondo de Cultura Economica; 1999. p. 139-60.

32. Sabates R, Feinstein L. The role of education in the uptake of preventative health care: the case of cervical screening in Britain. Soc Sci Med 2006; 62:2998-3010.

33. Subramanian SV, Kawachi I. Income inequality and health: what have we learned so far? Epidemiol Rev 2004; 26:78-91.

34. Gopi PG, Vasantha M, Muniyandi M, Chandrasekaran V, Balasubramanian R, Narayanan PR. Risk factors for non-adherence to Directly Observed Treatment (DOT) in a rural tuberculosis unit, South India. Indian J Tuberc 2007; 54:66-70.

35. Robirosa M. Micro-espacios, municipios y otras jurisdicciones locales. Problemas y recomendaciones para su tratamiento. In: Instituto Nacional de Estadística y Censos, editor. Aspectos teóricos y metodológicos relativos al diseño conceptual de la cédula censal. Buenos Aires: Instituto Nacional de Estadística y Censos; 1996. p. 630. (Serie D, 2).

Submitted on $16 / \mathrm{Feb} / 2014$

Final version resubmitted on 24/Mar/2015

Approved on 30/Mar/2015 